\title{
Soil microbial properties under permanent grass, conventional tillage, and no-till management in South Dakota
}

\author{
Lynne Carpenter-Boggs ${ }^{\mathrm{a}, *}$, Peter D. Stahl ${ }^{\mathrm{b}}$, \\ Mike J. Lindstrom ${ }^{\mathrm{c}}$, Tom E. Schumacher ${ }^{\mathrm{d}}$ \\ a Department of Plant Pathology, Washington State University, PO Box 646430, Pullman, WA 99164-6430, USA \\ ${ }^{\mathrm{b}}$ Department of Renewable Resources, University of Wyoming, Laramie, WY 82071, USA \\ ${ }^{c}$ United States Department of Agriculture, Agricultural Research Service, 803 Iowa Avenue, Morris, MN 56267, USA \\ d Plant Science Department, South Dakota State University, Brookings, SD 57007, USA
}

Received 16 May 2001; received in revised form 29 November 2002; accepted 3 December 2002

\begin{abstract}
The objective of this study was to determine how no-till and conventional tillage affected microbial properties of soil quality, using permanent grass fields as a standard of local high-quality soils. Agricultural fields in South Dakota were matched within soil type and location so that each set contained one field managed in permanent grass cover, one managed for annual crops using conventional tillage, and one managed for annual crops using no-till. Microbial biomass and activities, particularly those related to nitrogen and phosphorus availability were examined in $0-15 \mathrm{~cm}$ soil samples. Most measures of microbial activity were similar in the two annually cropped management systems but less than under permanent grass. Soils managed under permanent grass contained approximately $160 \%$ greater labile carbon and 50\% greater microbial biomass, and supported approximately $150 \%$ greater dehydrogenase enzyme activity, $50 \%$ greater respiration, and $180 \%$ greater acid phosphatase activity, than no-till and conventionally tilled soils, which were similar in these measures. Grassed soils also mineralized $460 \%$ greater $\mathrm{N}$ under anaerobic conditions and $80 \%$ greater $\mathrm{N}$ under aerobic conditions, while potential nitrification was $25 \%$ greater on average than cropped soils. Mycorrhizal fungi colonized $76 \%$ of observed root segments under grass, $63 \%$ under no-till, and 55\% under conventional tillage. Among the suite of tests in this study, only alkaline phosphatase activity and $\mathrm{C}$ mineralized in 12 days were significantly different under no-till and conventional tillage, both greater under no-till. Crops grown in a no-till system may be expected to resist low available $\mathrm{P}$ as well as other stresses better than crops in conventionally tilled soils due to greater activity of alkaline phosphatase and marginally increased mycorrhizal colonization of roots. No-till management in central South Dakota has allowed enhancement of readily mineralizable C and alkaline phosphatase activity. (C) 2002 Elsevier Science B.V. All rights reserved.
\end{abstract}

Keywords: No-till; Microbial activity; C and N mineralization; Phosphatase; Direct seeding

\footnotetext{
* Corresponding author. Tel.: +1-509-335-6483; fax: +1-509-335-9581.

E-mail address: lcboggs@wsu.edu (L. Carpenter-Boggs).
}

\section{Introduction}

Most arable land in South Dakota has been managed using intensive tillage since the beginning of the twentieth century or earlier. Few productive sites have been left undisturbed, but some have been used for permanent perennial grass pastures rather than annual 
crop land. Severe soil erosion and USDA conservation requirements have led to widespread adoption of reduced tillage methods in the last quarter of the 20th century. At the current time, chisel and disk tillage are common and have replaced the moldboard plow as primary tillage on many farms. In the past 20 years no-till or direct seeding methods have gained interest for their potential to further reduce soil erosion, fuel and labor costs, and equipment wear. Many studies show that reduced and no-till systems increase aggregate stability and reduce erosivity in the susceptible surface layer (Kladivko et al., 1986; Bruce et al., 1995).

Concomitant with the goals of erosion and cost reduction there is a growing belief that no-till systems benefit crop-enhancing soil biota. Soil-dwelling organisms can benefit crop production by releasing available forms of nutrients from soil organic and inorganic sources, fixing $\mathrm{N}$ within plant roots, increasing $\mathrm{P}$ uptake, and pathogen antagonism. Biotic soil quality factors in surface soil may be inversely related to tillage intensity (Angers et al., 1993). Several studies have indicated that no-till increases soil microbial biomass $\mathrm{C}$, total C, ratio of biomass C to total C (Granatstein et al., 1987; Angers et al., 1993), and the activity of several soil enzymes (Dick, 1984; Pagliai and De Nobili, 1993 ) in the surface $5-7.5 \mathrm{~cm}$, but these differences in activity between high- and low-intensity tillage treatments are commonly reversed in the subsurface.
Other management factors such as crop rotation often have a more dramatic effect on soil biotic factors throughout the Ap horizon (Dick, 1984, 1992). In a study by Bergstrom et al. (1998), soil enzyme activities were greater in no-till fields than conventionally tilled fields primarily where no-till soils were previously cropped to forages and conventionally tilled soils were cropped only to corn (Zea mays L.). In practice, farm fields differing in tillage systems will often also differ in cropping system, residue management, fertilization, etc. offering a systems comparison rather than a component analysis.

Our objective was to determine whether conversion to no-till increased general and nutrient-related microbial properties of soil quality over the common local reduced tillage methods, using permanent grass fields as a standard of local high-quality soils.

\section{Materials and methods}

Matched fields were identified at 11 sites in central South Dakota, in the upper Missouri River basin (Fig. 1). Each set included one field managed in permanent grass, one in row crops using no-till or direct seeding, and one in row crops using conventional tillage. Each field was in its current management system for a minimum of 6 years. Grass fields were used for pasture or hay production from bromegrass

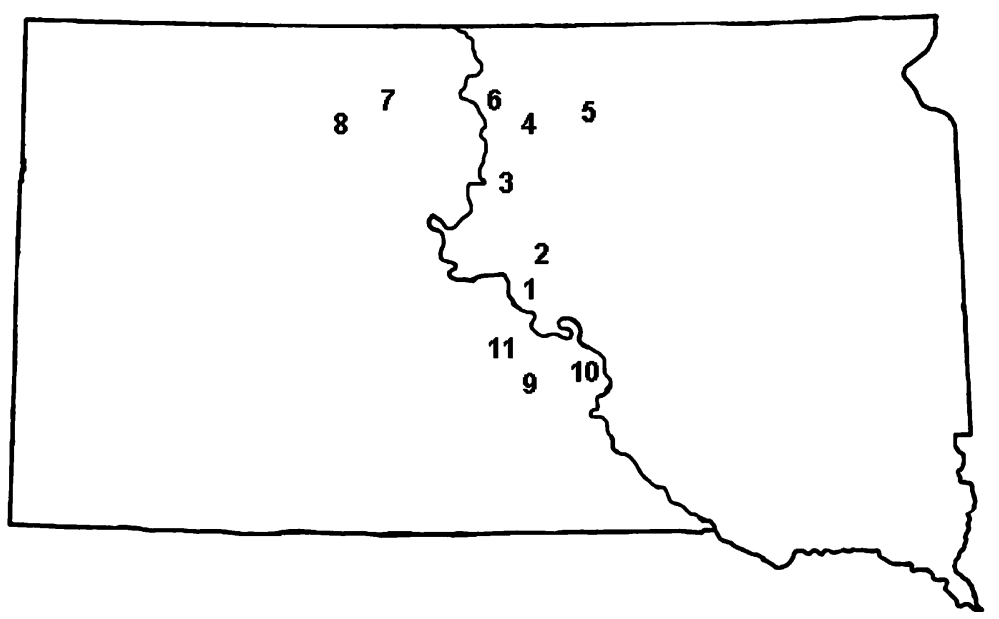

Fig. 1. Outline of South Dakota, with course of Missouri River and location of study sites numbered. Each site included one field in permanent grass, one field in no-till management, and one conventionally tilled field. 
Table 1

Soil description of sites in South Dakota managed under permanent grass, no-tilled row crops and conventionally tilled row crops

\begin{tabular}{rll}
\hline Site & Soil Series & Soil description $^{\text {a }}$ \\
\hline 1 & Highmore silt loam & Fine-silty, mixed, superactive, mesic Typic Argiustoll \\
2 & Highmore silt loam & Fine-silty, mixed, superactive, mesic Typic Argiustoll \\
3 & Lowry silt loam & Coarse-silty, mixed, superactive, mesic Typic Haplustoll \\
4 & Highmore silt loam & Fine-silty, mixed, superactive, mesic Typic Argiustoll \\
5 & Mondamin silty clay loam & Fine, smectic, frigid Vertic Argiustoll \\
6 & Agar silt loam & Fine-silty, mixed, superactive, mesic Typic Argiustoll \\
7 & Reeder loam & Fine-loamy, mixed, superactive, frigid Typic Argiustoll \\
8 & Vebar fine sandy loam & Coarse-loamy, mixed, superactive, frigid Typic Haplustoll \\
9 & Millboro silty clay & Fine, smectic, mesic Typic Haplustert \\
10 & Millboro silty clay & Fine, smectic, mesic Typic Haplustert \\
11 & Promise clay & Very fine, smectic, mesic Typic Haplustert \\
\hline
\end{tabular}

${ }^{a}$ USDA-NRCS Soil Survey Division official soil series description, http://ortho.ftw.nrcs.usda.gov/osd/osd.html.

(Bromus spp.), wheatgrass (Agropyron spp.), and/or bluegrass (Poa spp.). Most grass fields were never tilled but were seeded to change species composition and increase biomass production. Conventional tillage fields were usually chisel plowed to $7-20 \mathrm{~cm}$ depth as primary tillage with tandem disk as secondary tillage. Within each set, the three fields were in close proximity (within $4.3 \mathrm{~km}$ ) with similar soil profile (same soil series) and landscape position. Soils at all sites had an ustic moisture regime. Sites 1-8 were Mollisols ranging in texture from fine sandy loam to silty clay loam. Sites $9-11$ were Vertisols ranging in texture from silty clay to clay (Table 1). Crop rotations in no-till and tilled fields were similar and representative of local systems, but in many cases not identical. Rotations commonly included soybean (Glycine max [L.] Merr.), corn, sunflower (Helianthus annuus L.), and small grains particularly wheat (Triticum aestivum L.).

Fields were sampled in August 1998 and 1999 to a depth of $15 \mathrm{~cm}$. Within each field four areas of $100 \mathrm{~m}^{2}$ were selected for similarity and uniformity of topography and soil type. In 1998 four subsamples were composited and in 1999 two subsamples were composited by vertical coring with a small hand trowel in each of four selected areas per field. The four composite samples per field were stored at field moisture at $4{ }^{\circ} \mathrm{C}$ until analyses. Samples were sieved to $2 \mathrm{~mm}$ and visible organic matter was removed before analyses.

Mineralizable C (MinC) was determined with field moist soil (5 g dry weight) placed into $50 \mathrm{ml}$ vials, brought to $50 \%$ water-filled pore space, capped with septa, and incubated 12 days at $25^{\circ} \mathrm{C}$ in darkness. At the end of 12 days, total $\mathrm{CO}_{2}$ released was measured using a Varian 3700 gas chromatograph (Varian Inc., Walnut Creek, CA) with Porapak Q packed column and thermal conductivity detector (Davidson et al., 1987). Vials were uncapped and incubated overnight at $25{ }^{\circ} \mathrm{C}$, then recapped for $2 \mathrm{~h}$, and $\mathrm{CO}_{2}$ concentration of headspace was measured again to determine basal respiration rate. Substrate induced respiration (SIR) was subsequently measured using the same soil samples, following an addition of nutrient solution recommended by Smith et al. (1985), rather than glucose solution. Vials were uncapped and incubated at $25^{\circ} \mathrm{C}$ overnight, then $0.25 \mathrm{ml}$ of nutrient solution was added, containing $20 \mathrm{~g}$ nutrient broth, $4 \mathrm{~g} \mathrm{~K}_{2} \mathrm{HPO}_{4}, 1 \mathrm{~g} \mathrm{KH}_{2} \mathrm{PO}_{4}, 0.5 \mathrm{~g} \mathrm{MgSO}_{4} \cdot \mathrm{H}_{2} \mathrm{O}, 90 \mathrm{~g}$ glucose, and $20 \mathrm{~g} \mathrm{NH}_{4} \mathrm{NO}_{3} \mathrm{l}^{-1}$. Moisture content of samples for SIR was approximately $60 \%$ water-filled pore space. Vials were capped for $2 \mathrm{~h}$, and $\mathrm{CO}_{2}$ concentration of headspace measured again. Substrate induced respiration in $\mu \mathrm{lCO}_{2} \mathrm{~g}^{-1}$ soil h$^{-1} \times 40.4+0.37$ was used to estimate $\mu \mathrm{g}$ microbial biomass $\mathrm{C} \mathrm{g}^{-1}$ soil (Anderson and Domsch, 1978).

Dehydrogenase activity was measured using a colorimetric procedure involving reduction of triphenyl tetrazolium chloride to triphenyl formazan (Tabatabai, 1994). Reduced products were extracted with methanol, centrifuged, and the supernatant's absorbance was read at $490 \mathrm{~nm}$ with a microtiter plate-scanning spectrophotometer, Dynatech MR5000 (Dynatech Laboratories Inc., Chantilly, VA). Monophosphoesterase (phosphatase) activity was measured in soil solution buffered at $\mathrm{pH} 6.5$ (acid phosphatase) and $\mathrm{pH}$ 
11 (alkaline phosphatase) with disodium $p$-nitrophenol phosphate as enzyme substrate (Tabatabai, 1994). Samples were incubated $1 \mathrm{~h}$ at $37^{\circ} \mathrm{C}$. Control tubes were not supplied with disodium $p$-nitrophenol phosphate until after incubation. Quantity of $p$-nitrophenol released by enzyme activity in test tubes and non-enzymatic yellowing of solution in control tubes was measured by spectrophotometer absorbance at $405 \mathrm{~nm}$. Control was subtracted from both acid and alkaline enzyme activity estimate for each soil. Respiration and enzyme analyses were performed in quadruplicate for each field.

Initial soluble $\mathrm{N}$ was extracted from $5 \mathrm{~g}$ soil samples in $40 \mathrm{ml}$ of $1 \mathrm{M} \mathrm{KCl}$. Anaerobic $\mathrm{N}$ mineralization was measured in $5 \mathrm{~g}$ soil samples incubated 7 days at $35^{\circ} \mathrm{C}$ in $20 \mathrm{ml}$ deionized water, sealed under $\mathrm{N}_{2}$ gas (Drinkwater et al., 1996). Vials were extracted with $20 \mathrm{ml}$ of $2 \mathrm{M} \mathrm{KCl}$. Potential nitrification and aerobic $\mathrm{N}$ mineralization were measured in $8 \mathrm{~g}$ soil samples incubated 21 days at $35^{\circ} \mathrm{C}$ with $60 \%$ total water-filled pore space (Schmidt and Belser, 1994). Samples tested for potential nitrification were amended prior to incubation with $160 \mu \mathrm{g} \mathrm{g}^{-1} \mathrm{NH}_{4}-\mathrm{N}$ as $\left(\mathrm{NH}_{4}\right)_{2} \mathrm{SO}_{4}$. Vials were extracted with $1 \mathrm{M} \mathrm{KCl}$. All $\mathrm{NO}_{3}$ and $\mathrm{NH}_{4}$ determinations were made using an Alpkem autoanalyzer (O.I. Corp., College Station, TX). Soluble N $\left(\mathrm{NH}_{4}+\mathrm{NO}_{3}\right)$ at the end of incubation minus soluble $\mathrm{N}$ prior to incubation was used to determine aerobic or anaerobic $\mathrm{N}$ mineralization. Nitrate present in incubated soils amended with $\left(\mathrm{NH}_{4}\right)_{2} \mathrm{SO}_{4}$ was considered potential nitrification. Nitrogen incubation tests were performed in duplicate or quadruplicate as needed to clarify observations on field composite samples. Soil $\mathrm{pH}$ was measured with a glass electrode from $5 \mathrm{~g}$ soil in $10 \mathrm{ml} 0.01 \mathrm{M} \mathrm{CaCl}_{2}$ (Watson and Brown, 1998).
Composite soil samples taken in 1999 were used for assessment of mycorrhizal roots. Samples from sites 3,4 , and 11 in 1999 were not analyzed due to the absence of fresh roots in some fields at these sites at the time of sampling in August. Roots were removed from soil, soaked in water overnight, then cleared in $60^{\circ} \mathrm{C}$ $1.8 \mathrm{M} \mathrm{KOH}$ for $10 \mathrm{~min}$. Fungal tissues were stained with $0.66 \mathrm{~g}^{-1}$ trypan blue in lactoglycerol made of 1:1:1 lactic acid, glycerin, and water, then destained in lactoglycerol without trypan blue. Mycorrhizal fungal colonization was assessed under light microscope using the method of Allen and Allen (1980). Three composite root subsamples were assessed from each composite field soil sample, using 30 observation points on each composite root subsample.

Data were analyzed using Systat 9 (SPSS Inc., Chicago, IL). Treatment and site means were compared using paired $t$-tests of tilled and no-till treatments.

\section{Results}

The suite of respiration tests MinC, respiration, and SIR, as well as dehydrogenase activity, acid and alkaline phosphatase, and anaerobic $\mathrm{N}$ mineralization clearly differentiated soils under either tillage system with annual cropping from soils under permanent grass. Soils under permanent grass contained greater labile carbon and support greater microbial biomass and activities than annually cropped soils regardless of tillage regime (Tables 2 and 3).

Most measures did not differentiate tilled and no-till soils (Tables 2 and 3). Soil respiration rate, SIR, dehydrogenase activity, soil $\mathrm{pH}$, anaerobic $\mathrm{N}$ mineralization, and acid phosphatase were similar in both tillage

Table 2

Mean ( \pm S.E.) and $t$-test (no-till vs. tilled) of 12 days mineralized carbon, soil respiration rate, microbial biomass, dehydrogenase activity, and $\mathrm{pH}$ in soils under permanent grass, conventional tillage, and no-till in South Dakota

\begin{tabular}{llllll}
\hline Management & $\begin{array}{l}\mathrm{MinC}^{\mathrm{a}} \\
(\mu \mathrm{g} \mathrm{C} \mathrm{kg}\end{array}$ & $\begin{array}{l}\text { Respiration } \\
\left(\mu \mathrm{gCO}_{2}-\mathrm{Cg}^{-1} \text { soil h }\right.\end{array}$ & $\begin{array}{l}\text { SIR } \\
\left(\mu \mathrm{g} \mathrm{C}_{\mathrm{mic}} \mathrm{g}^{-1} \text { soil }\right)\end{array}$ & $\begin{array}{l}\text { Dehyd-ase activity } \\
\left(\mu \mathrm{g} \mathrm{g}^{-1} \mathrm{soil} \mathrm{h}^{-1}\right)\end{array}$ \\
\hline Grass & $206(39)$ & $7.0(0.8)$ & $919(77)$ & $4.1(0.6)$ & $\mathrm{pH}$ \\
No-till & $96(15)$ & $4.7(0.3)$ & $607(49)$ & $1.7(0.2)$ & $6.0(0.2)$ \\
Tilled & $62(8)$ & $4.7(0.4)$ & $619(39)$ & $1.6(0.2)$ & $5.9(0.3)$ \\
No-till vs. tilled & $0.01(P>F)$ & NS $(P>F)$ & NS $(P>F)$ & NS $(P>F)$ & NS $(P>F)$ \\
\hline
\end{tabular}

\footnotetext{
${ }^{\text {a }}$ MinC, 12 days mineralizable C; respiration, soil respiration rate; SIR, microbial biomass by substrate induced respiration; Dehyd-ase, dehydrogenase activity.
} 
Table 3

Mean $( \pm$ S.E.) and $t$-test (no-till vs. tilled) of nitrogen mineralization and nitrification rates, phosphatase activity, and mycorrhizal colonization in soils under permanent grass conventional tillage, and no-till in South Dakota

\begin{tabular}{|c|c|c|c|c|c|c|}
\hline Management & $\begin{array}{l}\text { Anaerobic } \mathrm{N}^{\mathrm{a}} \\
\left(\mu \mathrm{g} \mathrm{NH}_{4}-\mathrm{Ng}^{-1} \text { soil }\right)\end{array}$ & $\begin{array}{l}\text { Aerobic } \mathrm{N} \\
\left(\mu \mathrm{gO}_{3}-\mathrm{Ng}^{-1} \text { soil }\right)\end{array}$ & $\begin{array}{l}\text { Potential Nit } \\
\left(\mu \mathrm{g} \mathrm{NO}_{3}-\mathrm{Ng}^{-1} \text { soil }\right)\end{array}$ & $\begin{array}{l}\text { AcidP-ase } \\
\left(\mu \mathrm{g} \mathrm{NP} \mathrm{g}^{-1} \text { soil h}^{-1}\right)\end{array}$ & $\begin{array}{l}\text { AlkP-ase } \\
\left(\mu \mathrm{g} \mathrm{NP} \mathrm{g}^{-1} \text { soil h}^{-1}\right)\end{array}$ & Mycorrhizae \\
\hline Grass & $8.92(2.8)$ & 48.1 (14) & $122(13)$ & 813 (118) & $565(59)$ & $76(6)$ \\
\hline No-till & $1.57(1.4)$ & 32.7 (12) & $108(12)$ & $300(75)$ & $325(48)$ & $63(7)$ \\
\hline Tilled & $1.62(1.5)$ & $20.9(7.5)$ & $86.6(5.7)$ & $283(43)$ & 190 (37) & $55(5)$ \\
\hline No-till vs. tilled & $\mathrm{NS}(P>F)$ & $0.07(P>F)$ & $0.07(P>F)$ & $\mathrm{NS}(P>F)$ & $0.02(P>F)$ & $\mathrm{NS}(P>F)$ \\
\hline
\end{tabular}

${ }^{a}$ Anaerobic N, anaerobic N mineralization; Aerobic N, aerobic N mineralization; Potential Nit, potential nitrification; AcidP-ase, acid phosphatase; AlkP-ase, alkaline phosphatase; Mycorrhizae, mycorrhizal colonization (\% mycorrhizal root segments). 
Table 4

Correlation ( $r$ and significance level of $r$ ) of soil biological tests of permanent grass, no-till, and tilled fields

\begin{tabular}{|c|c|c|c|c|c|c|c|c|c|c|c|}
\hline & $\operatorname{MinC}^{\mathrm{a}}$ & Respiration & SIR & Dehyd-ase & AcidP-ase & AlkP-ase & Anaerobic N & Aerobic $\mathrm{N}$ & Potential Nit & Mycorrhizae & $\mathrm{pH}$ \\
\hline MinC & & $*$ & $*$ & $* *$ & $*$ & $*$ & $\mathrm{NS}^{\mathrm{b}}$ & $* *$ & $*$ & NS & NS \\
\hline Respiration & 0.68 & & $*$ & $*$ & $* *$ & $*$ & $*$ & $*$ & NS & NS & NS \\
\hline SIR & 0.66 & 0.66 & & NS & $*$ & $*$ & $*$ & NS & NS & NS & NS \\
\hline Dehyd-ase & 0.69 & 0.68 & 0.43 & & $* *$ & NS & NS & NS & $*$ & NS & NS \\
\hline AcidP-ase & 0.64 & 0.72 & 0.52 & 0.77 & & NS & NS & NS & NS & NS & NS \\
\hline AlkP-ase & 0.58 & 0.55 & 0.63 & 0.47 & 0.44 & & $*$ & NS & $*$ & NS & NS \\
\hline Anaerobic $\mathrm{N}$ & 0.47 & 0.57 & 0.63 & 0.29 & 0.29 & 0.58 & & NS & NS & NS & NS \\
\hline Aerobic N & 0.70 & 0.55 & 0.33 & 0.42 & 0.41 & 0.29 & 0.41 & & $* *$ & NS & NS \\
\hline Potential Nit & 0.66 & 0.50 & 0.25 & 0.54 & 0.38 & 0.53 & 0.43 & 0.80 & & NS & NS \\
\hline Mycorrhizae & 0.27 & 0.19 & 0.14 & 0.39 & 0.22 & 0.35 & 0.19 & -0.01 & 0.39 & & NS \\
\hline $\mathrm{pH}$ & 0.04 & -0.12 & 0.20 & -0.07 & -0.39 & 0.45 & 0.04 & -0.16 & 0.13 & 0.25 & \\
\hline
\end{tabular}

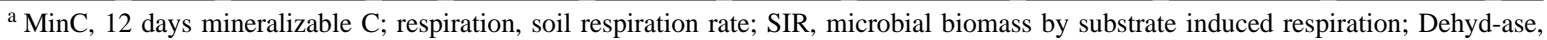
dehydrogenase activity; AcidP-ase, acid phosphatase; AlkP-ase, alkaline phosphatase; Anaerobic N, anaerobic N mineralization; Aerobic $\mathrm{N}$, aerobic $\mathrm{N}$ mineralization; Potential Nit, potential nitrification; Mycorrhizae, mycorrhizal colonization.

${ }^{\mathrm{b}}$ Not significant at $P=0.05$.

$* P<0.05$.

$* * P<0.01$

Table 5

Regression of alkaline phosphatase activity in relation to acid phosphatase (AcidP-ase), $\mathrm{pH}$, and management

\begin{tabular}{|c|c|c|c|c|}
\hline Equation & AcidP-ase & $\mathrm{pH}$ & Management $^{\mathrm{a}}$ & $r^{2}$ \\
\hline $235+0.269($ AcidP-ase $)$ & 0.01 & $\mathrm{NA}^{\mathrm{b}}$ & NA & 0.20 \\
\hline$-385+125(\mathrm{pH})$ & NA & 0.01 & NA & 0.20 \\
\hline$-1062+0.443($ AcidP-ase $)+205(\mathrm{pH})$ & 0.001 & 0.001 & NA & 0.66 \\
\hline$-754+0.266($ AcidP-ase $)+167(\mathrm{pH})+108($ management $)$ & 0.01 & 0.001 & 0.01 & 0.76 \\
\hline
\end{tabular}

${ }^{\text {a }}$ Management was used as a dummy variable in regression, with grass $=1$, no-till $=0$, and tilled $=-1$.

${ }^{b}$ Not applicable or not tested in this equation.

regimes. However, marginal improvement was evident in no-till soils with $56 \%$ greater aerobic $\mathrm{N}$ mineralization and $25 \%$ greater potential nitrification than in conventional tilled soils. Mycorrhizal colonization in roots of grass fields was 76\%, 63\% in no-till fields, and $55 \%$ in tilled fields (Table 3), though the difference between tilled and no-till fields was not significant.

Only MinC and alkaline phosphatase were significantly different between no-till and tilled soils. Carbon mineralized in a 12 days incubation was 55\% greater in soils managed under no-till than conventional tillage (Table 2). Alkaline phosphatase activity was $71 \%$ greater in no-till than tilled soil (Table 3).

Many of these soil biological measures were correlated. Notably, MinC and respiration were significantly correlated with most other biological properties, while soil $\mathrm{pH}$ was not significantly correlated to any biological property (Table 4). Alkaline phosphatase activity was correlated to several other measurements but not to soil $\mathrm{pH}$ or acid phosphatase activity (Table 4). However, alkaline phosphatase activity was predicted well by soil $\mathrm{pH}$ and acid phosphatase activity $\left(r^{2}=0.66\right)$ (Table 5$)$. Including soil management in the analysis increased correlation to $r^{2}=0.76$. Soil $\mathrm{pH}$ was not affected by management system (Table 2) and had only a weak positive correlation with alkaline phosphatase and a weak negative correlation with acid phosphatase (Table 4).

\section{Discussion}

Potential benefits of increased microbial biomass and activity are numerous. They include increased soil aggregate formation and stability, enhanced plant litter decomposition, increased nutrient cycling and transformations, slow-release storage of organic nutrients, and pathogen control. Additionally, microbial plant symbionts such as mycorrhizal fungi directly improve plant nutrient supply, stress tolerance, and 
productivity. A larger stable microbial population and greater activity may indicate greater soil quality (Turco et al., 1994).

Only MinC and alkaline phosphatase clearly differentiated no-till and till soils in the surface $15 \mathrm{~cm}$. Collins et al. (2000) also found that MinC accumulated at $0-20 \mathrm{~cm}$ under no-till, and showed that $\mathrm{C}$ mineralized in short-term incubations was derived primarily from recent crop residues. No-till management may allow MinC to build by reducing oxidation in the traditional plow layer.

Greater phosphatase activity has been observed previously in no-till than in conventionally tilled soil (Pagliai and De Nobili, 1993), particularly in fine textured soils (Bergstrom et al., 1998) and in upper surface soil layer from 0 to $7.5 \mathrm{~cm}$ (Dick, 1984; Angers et al., 1993). Dick (1984) observed greater acid phosphatase in both no-till soils but greater alkaline phosphatase in only one of two no-till soils than in tilled soils. Differences in acid and alkaline phosphatase between treatments and soils were closely related to soil organic $\mathrm{C}$ and $\mathrm{pH}$. At these sites total organic $\mathrm{C}$ differentiated grass and cropped soils, but not tilled and no-till soils (Schumacher et al., 2000). Alkaline phosphatase was only weakly correlated to soil $\mathrm{pH}(r=0.45$, Table 4$)$ and $\mathrm{pH}$ was not affected by tillage (Table 2), but did contribute significantly to regression analysis of alkaline phosphatase (Table 5).

No-till soils become stratified with greater organic matter, $\mathrm{N}$ mineralization potential, microbial biomass, respiration and enzyme activities near the soil surface and often lower measures of these properties in the shallow subsurface (Doran, 1980; El-Haris et al., 1983; Dick, 1984; Carter, 1986; Angers et al., 1993; Franzluebbers et al., 1994). From the $0-15$ or $0-20 \mathrm{~cm}$ plow layer, no-till and tilled soils are usually similar. It is unknown whether stratification of organic matter and microbial activities affects overall biological functioning of the soil, including biological nutrient availability.

Mycorrhizal roots were moderate to numerous in all treatments. Mycorrhizal colonization in no-till fields was intermediate to grass and tilled fields and more variable. Previous work has often found an inverse relationship between mycorrhizal colonization of roots and tillage intensity, although the relative increase in colonization may be temporary and appears to have little benefit on crop yield in a P-fertilized system
(Mulligan et al., 1985; McGonigle and Miller, 1993, 1996). Mycorrhizal colonization and responsiveness is also related to plant growth stage and crop species or variety (Hetrick et al., 1996), which can interact with tillage intensity and soil compaction (Mulligan et al., 1985; McGonigle and Miller, 1993). Therefore caution must be used in attributing differences in mycorrhizal colonization in working fields to tillage differences alone.

A number of other studies have shown greater differences in various biotic measures between no-till and tilled soils. In our study of working agricultural production fields many factors may have reduced the likelihood of significant differences between no-till and tilled soils. South Dakota is subjected to high winds and ustic moisture regime that create great potential for wind erosion. In order to reduce wind erosion and comply with conservation practices required for USDA programs, tillage intensity even in conventionally managed fields has declined in recent decades. Tilled fields in this study were normally chisel plowed and disked, not subjected to moldboard plow. Therefore the difference in tillage intensity between no-till and tilled treatments was not as great as in other studies that have compared no-till and moldboard plow treatments. Angers et al. (1993) observed greater differences in microbial biomass, water-soluble carbohydrates, and alkaline phosphatase activity between moldboard plow and chisel plow than between chisel plow and no-till. In most soil biological responses no-till and chisel plow treatments were similar, and both greater than moldboard plow. El-Haris et al. (1983) observed greater N mineralization potential in spring samples from no-till and chisel plowed soil than in moldboard plowed soil. These contrast the findings of Karlen et al. (1994) that chisel and moldboard plowed soils were similar and lower than no-till in microbial biomass, respiration, ergosterol, and aggregate $\mathrm{C}$ at $0-20 \mathrm{~cm}$ depth.

Changes in tillage are often accompanied by changes in crop rotation, cultivars, timing, or other factors that may also affect soil properties. Dick (1992) suggests that plant production and diversity may have a greater effect on soil microbial activity and diversity than reduced tillage where crop diversity remains low. Because in real systems tillage regimes are associated with vegetation and management histories, these effects cannot be entirely separated. Tilled 
and no-till soils of South Dakota were similar in most microbial properties as well as in cropping system, but both supported lower microbial biomass and activity than soils managed under permanent grass with no soil disturbance.

\section{Conclusion}

Measures of soil biotic properties in the traditional plow layer of South Dakota soils suggest that no-till soils are intermediate to grass and tilled soils, but no-tilled soils are still more similar to their tilled counterparts than to soils maintained under permanent grass. Recovery of soil quality from intensively tilled and/or degraded conditions may be accompanied or indicated by increase in microbial properties that are often correlated with total or labile soil carbon. The large difference between grassed soils and cropped soils may be due to the constant presence of vegetation and roots of permanent grass. The marginal differences between no-tilled and tilled soils may be due to the continuing advancement of conventional tillage regimes in South Dakota toward conservation tillage. In addition, the ustic moisture regime in this region may hinder soil carbon accumulation and thereby slow any increase in microbial properties under no-till.

\section{Acknowledgements}

We thank Justin Shirley for root mycorrhizal colonization assessment. We thank Terry Lemme, Nancy Barbour, and Graham Lief for other analyses. The USDA is an equal opportunity provider and employer.

\section{References}

Allen, M.F., Allen, E.B., 1980. Natural reestablishment of vesicular-arbuscular mycorrhizae following stripmine reclamation in Wyoming. J. Appl. Ecol. 17, 139-147.

Anderson, J.P.E., Domsch, K.H., 1978. A physiological method for the quantitative measurement of microbial biomass in soil. Soil Biol. Biochem. 10, 215-221.

Angers, D.A., Bissonnette, N., Légère, A., Samson, N., 1993. Microbial and biochemical changes induced by rotation and tillage in a soil under barley production. Can. J. Soil Sci. 73, $39-50$.
Bergstrom, D.W., Monreal, C.M., King, D.J., 1998. Sensitivity of soil enzyme activities to conservation practices. Soil Sci. Soc. Am. J. 62, 1286-1295.

Bruce, R.R., Langdale, G.W., West, L.T., Miller, W.P., 1995. Surface soil degradation and soil productivity restoration and maintenance. Soil Sci. Soc. Am. J. 59, 654-660.

Carter, M.R., 1986. Microbial biomass as an index for tillage-induced changes in soil biological properties. Soil Till. Res. 7, 29-40.

Collins, H.P., Elliott, E.T., Paustian, K., Bundy, L.G., Dick, W.A., Huggins, D.R., Smucker, A.J.M., Paul, E.M., 2000. Soil carbon pools and fluxes in long-term corn belt agroecosystems. Soil Biol. Biochem. 32, 157-163.

Davidson, E.A., Galloway, L.F., Strand, M.K., 1987. Assessing available carbon: comparison of techniques across selected forest soils. Commun. Soil Sci. Plant Anal. 18, 45-64.

Dick, W.A., 1984. Influence of long-term tillage and crop rotation combinations on soil enzyme activities. Soil Sci. Soc. Am. J. 48, 569-574.

Dick, R.P., 1992. A review: long-term effects of agricultural systems on soil biochemical and microbial parameters. Agric. Ecosyst. Environ. 40, 25-36.

Doran, J.W., 1980. Soil microbial and biochemical changes associated with reduced tillage. Soil Sci. Soc. Am. J. 44, 765774.

Drinkwater, L.E., Cambardella, C.A., Reeder, J.D., Rice, C.W., 1996. Potentially mineralizable nitrogen as an indicator of biologically active soil nitrogen. In: Doran, J.W., Jones, A.J. (Eds.), Methods for Assessing Soil Quality, SSSA Special Publication No. 49. Soil Science Society of America Inc., Madison, WI, pp. 217-229.

El-Haris, M.K., Cochran, V.L., Elliott, L.F., Bezdicek, D.F., 1983. Effect of tillage, cropping, and fertilizer management on soil nitrogen mineralization potential. Soil Sci. Soc. Am. J. 47, 1157-1161.

Franzluebbers, A.J., Hons, F.M., Zuberer, D.A., 1994. Long-term changes in soil carbon and nitrogen pools in wheat management systems. Soil Sci. Soc. Am. J. 58, 1639-1645.

Granatstein, D.M., Bezdicek, D.F., Cochran, V.L., Elliott, L.F., Hammel, J., 1987. Long-term tillage and rotation effects on soil microbial biomass, carbon and nitrogen. Biol. Fertil. Soils 5, 265-270.

Hetrick, B.A.D., Wilson, G.W.T., Todd, T.C., 1996. Mycorrhizal response in wheat cultivars: relationship to phosphorus. Can. J. Bot. 74, 19-25.

Karlen, D.L., Wollenhaupt, N.C., Erbach, D.C., Berry, E.C., Swan, J.B., Eash, N.S., Jordahl, J.L., 1994. Long-term tillage effects on soil quality. Soil Till. Res. 32, 313-327.

Kladivko, E.J., Griffith, D.R., Mannering, J.V., 1986. Conservation tillage effects on soil properties and yield of corn and soyabeans in Indiana. Soil Till. Res. 8, 277-287.

McGonigle, T.P., Miller, M.H., 1993. Mycorrhizal development and phosphorus absorption in maize under conventional and reduced tillage. Soil Sci. Soc. Am. J. 57, 1002-1006.

McGonigle, T.P., Miller, M.H., 1996. Mycorrhizae, phosphorus absorption, and yield of maize in response to tillage. Soil Sci. Soc. Am. J. 60, 1856-1861. 
Mulligan, M.F., Smucker, A.J.M., Safir, G.F., 1985. Tillage modifications of dry edible bean root colonization by VAM fungi. Agron. J. 77, 140-144.

Pagliai, M., De Nobili, M., 1993. Relationships between soil porosity, root development and soil enzyme activity in cultivated soils. Geoderma 56, 243-256.

Schmidt, E.L., Belser, L.W., 1994. Autotrophic nitrifying bacteria. In: Weaver, R.W., Angle, S., Bottomley, P., Bezdicek, D., Smith, S., Tabatabai, A., Wollum, A. (Eds.), Methods of Soil Analysis, Part 2, Microbiological and Biochemical Properties, SSSA Book Series No. 5. Soil Science Society of America Inc., Madison, WI, pp. 159-177.

Schumacher, T.E., Lindstrom, M.J., Eynard, A., Malo, D.D., 2000. Tillage system effects on soil structure in the upper Missouri River basin. In: Morrison Jr., J.E. (Ed.), Proceedings of the 15th International Conference of the International Soil Tillage Research Organization, ISTRO-2000.
Smith, J.L., McNeal, B.L., Cheng, H.H., 1985. Estimation of soil microbial biomass: an analysis of the respiratory response of soils. Soil Biol. Biochem. 17, 11-16.

Tabatabai, M.A., 1994. Soil enzymes. In: Weaver, R.W., Angle, S., Bottomley, P., Bezdicek, D., Smith, S., Tabatabai, A., Wollum, A. (Eds.), Methods of Soil Analysis, Part 2, Microbiological and Biochemical Properties, SSSA Book Series No. 5. Soil Science Society of America Inc., Madison, WI, pp. 775-833.

Turco, R.F., Kennedy, A.C., Jawson, M.C., 1994. Microbial indicators of soil quality. In: Doran, J.W., Coleman, D.C., Bezdicek, D.F., Stewart, B.A. (Eds.), Defining Soil Quality for a Sustainable Environment, SSSA Special Publication No. 35. Soil Science Society of America Inc., Madison, WI, pp. 73-90. Watson, M.E., Brown, J.R., 1998. pH and lime requirement. In: Recommended Chemical Soil Test Procedures for the North Central Region, North Central Regional Research Publication No. 221 (revised), pp. 13-16. 